\title{
ЭНДОГЕННЫЕ КАРДИОТОНИКИ. СОВРЕМЕННЫЕ ПРЕДСТАВЛЕНИЯ И ПЕРСПЕКТИВЫ
}

\author{
А.Р. Колпаков, Р.А. Князев, Н.В. Трифонова, А.В. Рябченко, \\ М.В. Котова, Е.И. Соловьева, Л.М. Поляков \\ Федеральное государственное бюджетное научное учреждение «Федеральный \\ исследовательский центр фундаментальной и трансляционной медицины» \\ Научно-исследовательский институт биохимии (НИИ биохимии ФИЦ ФТМ), \\ 630117, г. Новосибирск, ул. Тимакова, 2.
}

DOI: 10.19163/MedChemRussia2021-2021-143

E-mail:kolpakov2@yandex.ru

Хроническая сердечная недостаточность (ХCH) является бичом современного цивилизованного мира. За последние полвека пересадка сердца стала золотым стандартом лечения больных с тяжелой сердечной недостаточностью (CH). Но лекарственная терапия продолжает оставаться ведущей в комплексном лечении больных с СН. Поиск эффективных кардиотоников ведётся как среди природных и синтезируемых ксенобиотиков, так и в самом организме. Усиливать сократимость миокарда способны многие эндогенные соединения, как низкомолекулярные, так и более сложные, в том числе и пептиды. Однако необходимым условием признания их кардиотониками, позитивно влияющими на течение и прогноз ХCH, должна быть их способность длительно и стабильно повышать работоспособность миокарда без значительного увеличения потребления кислорода, как это свойственно классическим адреномиметикам. До настоящего времени такими применяемыми в клинике соединениями являются гликозиды наперстянки. Поиски кардиостероидов в организме привели к обнаружению эндогенных оубаина и дигоксина. Имея сходный механизм кардиотонического действия, они отличаются токсическими и сосудистыми эффектами.

При изучении биологических свойств сывороточных липопротеинов в НИИ биохимии выявлена способность липопротеинов высокой плотности (ЛПВП) увеличивать амплитуду и частоту сокращений изолированного сердца крысы. Позднее было установлено, что повышение сократительной способности миокарда (на 30-70\% в зависимости от исходного состояния) обусловлено входящим в состав ЛПВП апопротеином A-I (апоА-I), при этом потребление кислорода сердцем на единицу выполненной работы снижалось.

В продолжение этих работ в НИИ биохимии получен рекомбинантный аполипопротеин А-І (рапоА-І) с молекулярной массой 28 кДа, который по первичной структуре и своим физико-химическим свойствам соответствует нативной форме апоА-І и отличается только отсутствием двух аминокислот с N-конца. В экспериментах на изолированном по Лангендорфу сердце крысы рапоА-І полностью воспроизводил эффекты нативного апоА-І, что позволяет рассматривать его как перспективное для дальнейших исследований соединение. 